\title{
Error Analysis on Learners' Interlanguage and Intralanguage: A Case Study of Two Adolescent Students
}

\author{
Dian Puspita \\ dian.puspita@teknokrat.ac.id \\ Universitas Teknokrat Indonesia
}

\begin{abstract}
This research focuses on exploring learners' language, especially the errors that are performed by the English learners. The subjects of this study are two adolescent students who have been learning English since early age. The data analyzed is collected by doing the interview session. Identification and classification are done toward the errors performed by the subjects. After that, the pattern is drawn to find out the subjects' nature of language. The result shows that both interlanguage and intralanguage affect the students' English. However, interlanguage affects the errors more than does intralanguage. It proves that the nature of L1 affects the L2 acquisition. The errors occurred in terms of subject-verb agreement, tenses, and relative clause. At the end, the appropriate feedback given to speaking performance is implicit correction such as recast and prompts.
\end{abstract}

Keywords: Error analysis, feedback, intralanguage, interlanguage

\section{Introduction}

In language learning, errors performed by the learners have become an issue and concern to be analyzed. Corder (1982) mentioned that there are two justifications underlying the significance of learners' error study, namely pedagogical justification which is "understanding of the nature of error is necessary before a systematic means of eradicating them could be found", and theoretical justifications which claims that 'a study of learners' errors is part of the systematic study of the learners' language which is itself necessary to an understanding of the process of second language acquisition (SLA)". From these two justifications, it can be said that analyzing learners' errors can improve the teaching materials and techniques, and we can also find out the nature of the interlanguage which affects the learners' errors. In a sense of second language context, it is clearly shown that the presence of first language can influence the errors occurrence in second language learnt (Selinker as cited in Lightbown and Spada, 2013). Richards (2015) also pointed out the significance of learners' error as the means for teachers to see the L1 interference toward target language learnt. The inventory of learners' error would come to teachers' attention so they can devote special care and emphasize the teaching process to overcome or avoid the predicted difficulties faced by learners.

For its significance mentioned earlier, many studies in error analysis in SLA context have been conducted as a way to explore learners' language. Bedmar (2005), Shan-ling (2012), Wu and Garza (2014) conducted an error analysis study toward college students and found out the interlingual and intralingual errors performed in students' writing. Bennui (2016) also studied the basic writing of third-year English-minor students. He found that literal translation of Thai words into English represented features of L1 lexical interference in the students' written English. In addition, Taher (2011) investigated the errors appeared in Swedish junior high school students' writing by comparing free writing and controlled writing. The results showed that both writings produced grammatical errors, but in different aspect; free writings produce more prepositional errors and controlled writings produced 
more subject verb agreement errors. Hmouma (2014) also studied the error analysis of third year High School students and found a great deal of students' errors could be explained by overgeneralization and interference from students' mother tongue. From these studies mentioned, it was shown that the researchers conducted the study toward the writing performance. However, in this paper, the errors performed by learners are analyzed in different aspect; speaking performance. Later we can see how the writing and speaking corpus may differ in term of errors performed and feedback given. Also, this paper discussed the learners' interlanguage factor and intralanguage factors in types of errors appeared in terms of their tenses, subject - verb agreement, and relative clause.

\section{Theory and Method}

The study is conducted in SLA context, especially in Indonesia context. It is a case study of two adolescent learners; one is college student and another one is junior high school student. The first learner named Sera is 19 years old second year college student. He has been learning English since he was 10 years old. His first language is Indonesian, and he is also speaking Sundanese as his other language. The second learner is a junior high school student named Elvina. She started learning English earlier when she was 9 years old. She is in the third grade and attends an international school. The other language she acquires is Indonesian as her first language. Similarly, both subjects had experience in joining an English course.

Different to the two previous studies, the corpus analyzed in this study is learners' speaking performance. The interviews were conducted to record learners' speaking performance. The interviews were addressed to answer the following research questions:

1. How does interlanguage affect the errors performed by learners?

2. What are the types of errors in terms of subject-verb agreement, tenses, and relative clauses appeared in the speaking performance?

3. What kind of feedback do the learners need?

The data is collected by recording the interview with the topic of "the motivation of learning English". The interviews took 9.42 ' and 6.01' respectively. The results then were transcribed to analyze. Analysis is done by identifying, classifying the errors, and explaining the errors and patterns. Some theoretical frameworks are used to analyze the data, such as types of error, tense aspect, English relative clause general stages, and feedback.

\section{Types of Error}

For subject and verb agreement, Amara (2015) drew and categorized the types of errors from Corder (1974) and Scovel (2001) into two: interlingual interference and intralingual interference. Interlingual interference is the errors caused by learners' mother tongue interference. Meanwhile, intralingual interference occurs because of the difficulty of language itself. Intralingual errors are categorized as over-generalization, simplification, communication base, induced errors, analogical errors, ignorance of rule restrictions, incomplete application of rules, and false hypothesis.

\section{Tense Aspect}

Meisel (1987) categorized the reference to past events into 4 stages. Stage 1 is the reference to events in the order in which they occurred; mention of time or place to show that the event occurred in the past. Stage 2 is when grammatical morpheme attached to the verb; frequent form-meaning mismatch. Stage 3 is when irregular past tense forms used 
before the regular past is used reliably. The last, stage 4 is when the regular $-e d$ ending over generalized.

\section{English Relative Clause General Stages}

In the sequence of acquisition of second language, Keenan and Comri (1997) made the hierarchal stages for English relative clauses into six stages. The stages are as follows.

$\begin{array}{cl}\text { Stage } & \text { Description } \\ 1 & \text { Subject } \\ 2 & \text { Direct object } \\ 3 & \text { Indirect object } \\ 4 & \text { Object of preposition } \\ 5 & \text { Possessive (Genitive) } \\ 6 & \text { Object of comparison }\end{array}$

\section{Feedback}

Tarone and Swierzbin (2009) identified basic kinds of corrective feedback into explicit and implicit corrections. Explicit correction directly informs learners the incorrect form and gives the correct form. Meanwhile, implicit correction consists of recast and prompts. In recast, the teacher reformulates all or part of the learner's utterance, providing a correct alternative, without explicitly signaling that it is a correction. A little bit different to recast, prompts do not provide alternative repair; prompts offer a variety of signals to push the learner to self-repair. Prompts themselves are divided into four; clarification request, elicitation, metalinguistic feedback, and repetition.

\section{Findings and Discussion}

Having the similar characters, both subjects started learning English in early age. For years, they have been studying English at school although not intensively. The findings showed the similarity and difference between both subjects. The errors performed by subjects were analyzed and categorized into some points; 1)subject and verb agreement, 2)tenses, and 3)relative clauses. They are presented as follow.

\section{Subject and Verb Agreement}

A number of subject-verb agreement errors occur in the learners' speaking performances. However, since the first subject, Sera, took longer time to speak, it can be seen that he performed more errors caused by more various types of errors. Differently, Elvina performed fewer numbers caused by only a single type of error. The details can be seen in the following table.

Table 1. Number of errors in Subject-Verb Agreement

\begin{tabular}{|l|c|l|c|}
\hline Types of error & Frequency & Types of error & Frequency \\
\hline Interlanguage & 6 & Simplification & 8 \\
\hline Overgeneralisation & 1 & Total errors & 8 \\
\hline Simplification & 6 & & \\
\cline { 1 - 2 } Analogical error & 1 & & \\
\cline { 1 - 2 } Incomplete application of rule & 3 & & \\
\cline { 1 - 2 } False hypothesis & 2 & & \\
\cline { 1 - 2 } Total errors & 19 & & \\
\cline { 1 - 2 } & & &
\end{tabular}

Of the 19 errors, Sera's errors are mostly caused by interlingual (6 errors) which happened in type of missing copula. Different to the target language, in his L1, the copula, 
which is represented in bracket, should not be present to function as the verb. Here are some examples of the all errors. Therefore, it can be said that what is considered right in L1 structure is considered error in TL.

TL

$\mathrm{Oh}$, when I (was) in the elementary ... my teacher (was) in front of the class When I (was) elementary school ....

When I (was) ten years old, ,... because English (was) not just ABCD... ... my teacher (was) in front of the class
SL

Ketika saya (adalah) di sekolah dasar ... guru saya (adalah) di depan ruang kelas Ketika saya (adalah) Sekolah Dasar Ketika saya (adalah) 10 tahun, Karena Bahasa Inggris (adalah) bukan hanya $A B C D$ ... guru saya (adalah) di depan kelas...

Another frequent error is caused by simplification. Sera performed 6 errors, while all of Elvina's errors are caused by it also. The simplifications occurred in $3^{\text {rd }}$ singular person verb form and plural noun.

Sera

... and it more increase our ...

... some English course

... give the students some material

... some conjunction
Elvina

, every one need English to communicate ..

, many country use English so much

, . Like every one, you know ,need to learn English

..and college use that

Similar to the previous error, this error could happen because of the L1 influence. In their L1, there are no different verb forms for any subject. Therefore, there is tendency the morpheme - s/es for $3^{\text {rd }}$ singular person verb form are simplified. Also, in their L1, the plurality is not signified by morpheme addition. Instead, it is signified by the adverb of quantity only.

Next, incomplete application of rule in which subject is missing also occurred in Sera's performance. False hypothesis, overgenerealisation, and analogical errors occurred less frequent. Comparing the two subjects, it can be said that both have similarity in performing subject-verb agreement errors in type of simplification. However, unlike Sera, Elvina just performed one type of error. Her ability in grammatical accuracy could be better compared to Sera because she has more exposure and bigger chance to practice her English considering she attends an international school.

\section{Tenses}

Using Meisel's tenses category, it is found that the past reference errors performed by the subjects occurred in different stages. Sera's past reference errors are all present in stage 1. In most cases, he mentioned the time when the events occurred, yet he failed to produce the correct grammatical structure. Following are two examples of Sera's past reference errors.

Uhm the first time is.. when I study in elementary school, and then I when I elementary I study in some..

Uhm, because my parents... tell me, the English is a universal language (talking about past motivation in learning English)

Similar to Sera, Elvina produced past reference error in stage 1 also.

..when I am in 14 years or 15 years old..

It help me. (talking about past event)

In addition to stage 1 error, different stages also occurred in Elvina's performance. Being aware of the use of past tense, she later became inconsistent in the use of tense. 
However, according to Meisel, the error below is considered in stage 2 for attaching grammatical morpheme.

\section{Actually when I was nine years old. You know, I don't like English. \\ But I don't know grammar and anything. (talking about past event)}

More interestingly, Elvina produced stage 4 error in which she used the wrong past tense form for the present reference. It is believed for her awareness of past reference, but she overgeneralised it when referring to present event also. Below she was talking about her chance to speak English with her brother and sister, but she cannot do it with the sister because the sister is going to go to Malaysia. However, instead of using future tense, she used past tense to refer it.

But my sister yea..went,,went to Malaysia.

Based on the errors performed by the learners, it can be seen that referring to the past is mostly troublesome. In fact, although the subject was aware of this past reference, she has problem in consistency. It is believed that these occurrences are influenced by subjects' interlanguage. In their L1, there is no change of verb form in referring to past events. Instead, they signify the past events with adverb of time only.

\section{Relative clauses}

In both subject's performances, there are very few number of relative clauses produced. Sera produced only 1 relative clause, and based on Keenan and Comri's sequences it is in stage 2. Meanwhile, Elvina also produced only 1 relative clause which is categorized as stage 4. The difference between these two relative clauses is that Sera performed error in it, but Elvina did not.

\section{Sera}

... about some technology that they talk and they writing something

Elvina

because it is the first language that we need to learn.

Stage 2 - direct object

Stage 4 - object of preposition

The few number of relative clause occurrences could happen for the learners' proficiency are not sufficient enough to produce more complex and longer utterance. Instead, they explained something further in the new sentences.

\section{Interlanguage Interference}

In term of the interference, it is stated by Corder (1974) that interlingual interference is the errors caused by learners' mother tongue interference. In the study it was found that most of the errors were interfered by subjects' L1. This is relevant to what Richard and Sampson (2015) called as language transfer. As one of factors influencing language learners' system, language transfer from L1 to target language frequently appeared in most cases. In this study, language transfer occurred in grammatical influence which resulted in all errors by subjects. Grammatical influence from L1 on the learners' production target language was characterized in subject and verb agreement, noun plural form, and tenses. In subject and verb agreement, the use of copula is mostly omitted because it does not function as the verb in L1. For the noun plural form, in subjects' L1, the plurality is not signified by morpheme addition. Lastly, the learners transferred the grammatical structure in L1 tenses to all time aspect. In L1, there are not the verb changes to refer to past, present, or future. Instead, the time signals occurred in the adverb of time. All in all, the production of target language in this study contained the errors which were interfered by L1 grammatical influence. This is in line with the findings of Widianingsih and Gulö (2016), and Fauziati (2017) which 
mentioned the typical errors performed by Indonesian learners in learning English. Knowing the pattern of the errors, the teachers can predict and anticipate the errors and make the teaching strategy to overcome the issue.

\section{Conclusion}

From the findings and analysis discussed, we can draw three conclusions. First, interlanguage has a role in affecting the occurrences of errors performed by the learners in term of grammatical structural accuracy: subject-verb agreement and tense. It is because in this case what is considered correct in L1 structure is considered incorrect in TL. This is in accordance with what Lightbown and Spada stated about error analysis "it has some characteristics influenced by previously learned languages". Secondly, the errors performed by the subjects in terms of subject-verb agreement caused are interlanguage and intralanguage interference (over-generalization, simplification, analogical error, incomplete application of rule, and false hypothesis). In term of tense, past reference errors occurred in stage 1, stage 2, and stage 4. For relative clause, it occurred just 2 times, and according to Keenan and Comry (1977), they are in stage 2 and stage 4 in sequence of acquisition. Lastly, we need to provide the appropriate feedbacks according to learners' need. As it is different with written language which can be given either explicit correction (Shan-Lin, 2012) or implicit correction (Taher, 2011), I believe in speaking context it is more appropriate to provide implicit correction. First, recast is good to provide learners the correct. However, if the learners keep repeating the errors without realizing the alternatives given, prompt correction will be better given. It is done to push the learners to perform self-repair. Providing the feedbacks, learners are supposed to get the uptakes and improve their proficiency. This is attached to interlanguage characteristic itself which is dynamic; interlanguage is constantly changing (Lightbown \& Spada, 2013).

\section{References}

Amara, N. 2015 Errors correction in foreign language teaching. The Online Journal of New Horizons in Education, 5(3), 58 - 68.

Bedmar, M. B. D. 2005. Struggling with English at University level: error patterns and problematic areas of first-year students' interlanguage. In Proceedings from the Corpus Linguistics Conference. Retrieved from http://www corpus.bham.ac.uk/.

Bennui, P. 2016. A study of L1 intereference in the writing of Thai EFL students. Malaysian Journal of ELT Research, 4(1), 31.

Corder, S. P. 1982. Error analysis and interlanguage. Oxford: Oxford University Press.

Fauziati, E. 2017. Native and target language influence on the students'interlanguage production: a case of Indonesian EFL compositions. Indonesian Journal of Applied Linguistics, 7(1), 54-63.

Hmouma, M. A. A. 2014. Interlanguage Syntax of the Noun Phrase in English: An Error Analysis of Third Year High School Students of English in Zawiya, Libya. IOSR Journal of Humanities and Social Science, 19(5), 36-43.

Keenan, E. and Comrie, B. 1977. Noun phrase accessibility and universal grammar. Linguistic Inquiry, 8, 63 - 99.

Lightbown, P. M., and N. Spada. 2013. How Languages are Learned 4th edition. Oxford University Press 
Meisel, J. 1987. Reference to past events and actions in the developmental of natural second language acquisition. In C. Pfaff (ed.), First and second language acquisition processes. Cambridge, MA: Newbury House.

Richard, J.C., and G. P. Sampson. 2015. The study of learner English. In Richards, J. C. Error analysis: Perspectives on second language acquisition (pp. 3-18). London: Routledge.

Richards, J. C. 2015. Error analysis: Perspectives on second language acquisition. London: Routledge.

Scovel, T. 2001. Learning New Languages. Boston: Heinle and Heinle.

Shan-ling, L. I. N. 2012. The application of error analysis in college English teaching. SinoUS English Teaching, 9(5), 1124-1131.

Taher, A. 2011. Error analysis : A study of Swedish junior high school students' texts and grammar knowledge (Dissertation). Retrieved from http://urn.kb.se/resolve?urn=urn:nbn:se:uu:diva-168388.

Tarone, E. and B. Swierzbin. 2009. Exploring learner language. Oxford: Oxford University Press.

Widianingsih, N. K. A. and Ingatan Gulö. 2016. Grammatical difficulties encountered by second language learners of English. Proceedings of ISELT FBS Universitas Negeri Padang, 4(2), 141-144.

Wu, H. P. and E. V. Garza. 2014. Types and Attributes of English Writing Errors in the EFL Context-A Study of Error Analysis. Journal of Language Teaching \& Research, 5(6). 